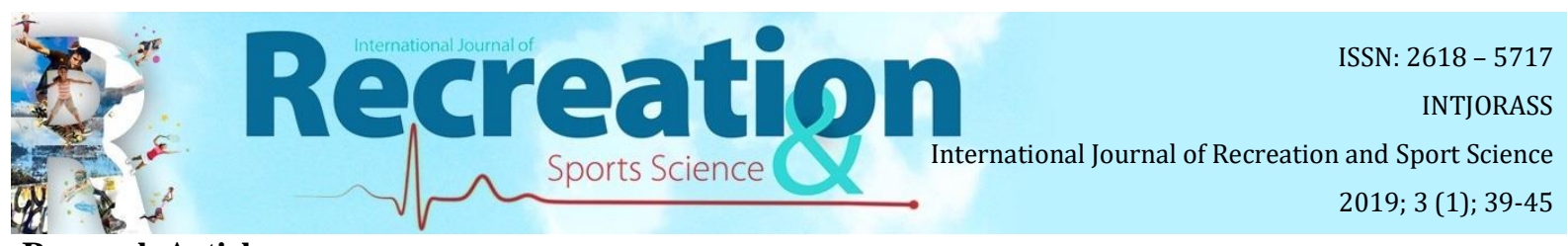

Research Article

\title{
Investigation of Sportsmanship Behaviors of Athletes Participating in Intercollegiate Basketball Competitions
}

\author{
Yıldırım Gökhan GENCER* $\quad$ Oğuzhan EROĞLU** ${ }^{* *}$ Yunus YILDIRIM***
}

\begin{abstract}
This study focused on investigating sportsmanship behaviors of athletes participating in intercollegiate basketball competitions. Study group was composed of 148 athletes participating in Intercollegiate Basketball Competitions organized in Mersin and Çorum Provinces during 2017-2018. In the study, "Sportsmanship Scale" was used as data collection tool. In the study, it was found that sportsmanship levels of athletes participating in basketball competitions was at moderate level and sportsmanship behaviors did not change statistically in terms of sex, department and position variables $p>0.05$. Besides, it may be argued that students attending School of Physical Education and Sports had higher level of sportsmanship as compared to students attending other departments.
\end{abstract}

Keywords: Basketball, Sportsmanship, Fair Play.

\section{Üniversitelerarası Basketbol Müsabakalarına Katılan Sporcuların Sportmenlik Davranışlarının İncelenmesi}

\begin{abstract}
$\ddot{O} \mathbf{z}$
$\mathrm{Bu}$ araştırmanın amacı; üniversitelerarası basketbol müsabakalarına katılan sporcuların sportmenlik davranışlarının incelenmesidir. Araştırmanın çalışma gurubunu; 2017-2018 yılında Mersin ve Çorum İllerinde düzenlenen üniversitelerarası basketbol müsabakalarına katılan 148 sporcu oluşturmuştur. Araştırmada veri toplama aracı olarak; "Sportmenlik Ölçeği" kullanılmıştır. Araştırmada; basketbol müsabakalarına katılan sporcuların, sportmenlik düzeylerinin orta üzeri seviyesinde olduğu ve sportmenlik davranışlarının, cinsiyet, bölüm ve pozisyon değiş̧kenlerine göre istatistiksel olarak anlamlı bir farklılık göstermediği tespit edilmiştir p>0.05. Ayrıca Beden Eğitimi ve Spor Yüksekokulunda öğrenim gören öğrencilerin, diğer bölümlerde öğrenim gören öğrencilere göre daha yüksek seviyede sportmenlik düzeyine sahip olduğu söylenebilir.
\end{abstract}

Anahtar Kelimeler: Basketbol, Sportmenlik, Fair Play.

\footnotetext{
* Mersin Üniversitesi, Spor Bilimleri Fakültesi, Mersin-Türkiye, e-posta: ygokhangencer@ gmail.com Orcid id: 00000001-5511-2374

** Mersin Üniversitesi, Spor Bilimleri Fakültesi, Mersin-Türkiye, e-posta: oguz-er1071@ @otmail.com Orcid id: 00000003-4046-6289

*** Mersin Üniversitesi, Spor Bilimleri Fakültesi, Mersin-Türkiye, e-posta: ynsyldrm69@ mersin.edu.tr Orcid id: 00000002-5851-7788 


\section{INTRODUCTION}

The term sport means such terms as peace, tolerance, equality, discipline, virtue, pleasure, justice, right, happiness, love and respect and other terms that are decent for human dignity as well as other human characteristics such as sadness, sorrow, stress and continues to be a term that influences whole existence of humans (Pehlivan, 2004). Sport, at the same time, refers basically to rivalry although it is a kind of combat that is done by using mind and body against an opponent, athlete himself, nature, distance and time in line with equally applied rules (Gürpınar and Güven, 2011).

Sportsmanship is defined as virtuous behaviors that explain how to behave in terms of spirit of sport (Stornes, Bru, 2002) and includes such characteristics as sincerity, courage, respect for others' opinions and truth, politeness, kindness, nobility, honorableness, partnership and generosity (Çalayır et al., 2017). Besides, it is known that participation in sport improves solidarity and cooperation feelings, creates an awareness to obey the rules and to share and increases tolerance, helpfulness (Özsarı, 2018). However, it is witnessed that behaviors that lack ethics have been seriously increasing in sport competitions and measures taken to prevent these negative behaviors are not enough (Tekeli, 2017). In this sense; it is thought that sportsmanship is a critically important term (Sensions, 2004). What athletes aim at is to win and to defeat but rewards and championships won by athletes' success should be a means rather than an end (Gümüş et al. 2016). To develop this idea is possible only with the feeling of sportsmanship existing in sport. To make this development occur positively is possible only by reviewing sportsmanship levels of athletes participating in sport competitions, by making relevant recommendations and by taking necessary measures.

When literature is looked at, it is noted that the number of studies on sportsmanship has been in the increase lately (Sezen Balçıkanlı and Yıldıran, 2011; Gürpınar and Kurşun, 2013; Gümüş et al., 2016; Sezen Balçıkanlı, Gülşen and Y1ldiran, 2017; Tel, Yaman and Altun, 2017; Güllü and Şahin, 2018; Özsar1, 2018; Özsarı, Demirel, Altın, Yalçın and Demir, 2018; Gümüş, 2019). However, it was found that there was no study on athletes participating in intercollegiate competitions. In this sense, we are of the opinion that the current study will make its contributions to the literature. Besides, most of the athletes participating in intercollegiate competitions were made up by those students attending School of Physical Education and Sports. Attitudes and behaviors demonstrated by these athletes in sport competitions naturally play a critical role in disseminating sport and exploring its uniting power.

This study aimed at investigating sportsmanship behaviors of athletes participating in intercollegiate basketball competitions.

\section{METHOD}

\section{Study Group}

Study group was composed of 148 athletes who were recruited with purposive sampling and participated in Intercollegiate Basketball Competitions organized in Mersin and Çorum Provinces during 2017-2018. $83.1 \%$ of the participants were male while $16.9 \%$ of them were female.

\section{Data Collection Tools}

In the study, Information Request Form that included questions addressing at 
Gençer Y. G., Eroğlu, O., Yıldırım, Y. (2019). Investigation of Sportsmanship Orientation of Athletes Attending to Intercollegiate Basketball Competitions. International Journal of Recreation and Sport Science, 3 (1); 39-45.

personal information and "Sportsmanship Scale" were used as data collection tool.

\section{Information Request Form}

The form included questions about participants' sex, age, department, position and parents' educational levels.

\section{Sportsmanship Scale}

"Sportsmanship Scale" developed by Gümüş et al., (2017) is consisted of 27 items and is a 5 point Likert type scale. The scale includes five subdimensions: "Rules", "Injurious Acts", "Opponent", "Game Perspective" and "Sportive Behavior". In the original scale, Cronbach
Alpha coefficient was found to be 0.94 while in this study it was 0.95 .

\section{Data Analyses}

Distribution of the data was examined in order to determine which analysis methods should be used and since the data did not follow a normal distribution, nonparametric tests were used. Therefore; descriptive statistical analyses, KruskalWallis $\mathrm{H}$ Test and Mann Whitney-U Test were employed in order to explore differences in independent variables. Cronbach Alpha coefficient was calculated in order to test reliability of the scale and the findings were presented in tables.

\section{RESULTS}

Table 1. Descriptive Statistics concerning Sportsmanship Scale Scores

\begin{tabular}{lccc}
\hline Sportsmanship & Rate-Range & $\overline{\mathbf{x}}$ & sd \\
\hline Rules & $1-5$ & 4.09 & 0.83 \\
\hline Injurious Acts & $1-5$ & 3.88 & 0.87 \\
\hline Opponent & $1-5$ & 4.13 & 0.86 \\
\hline Game Perspective & $1-5$ & 4.01 & 0.91 \\
\hline Sportive Behavior & $1-5$ & 4.15 & 0.89 \\
\hline General Total & $1-5$ & 4.06 & 0.68 \\
\hline
\end{tabular}

I Strongly Disagree (1.00-1.79). I Disagree (1.80-2.59). Partly Agree (2.60 3.39). Agree (3.40-4.19). Strongly Agree (4.20-5.00)

When Table 1 was examined, it was seen that Sportive Behavior of the Sportsmanship Scale produced the highest score $(\overline{\mathrm{x}}=4.15)$ while the lowest score was found in Injurious Acts $(\overline{\mathrm{x}}=3.88)$. Besides, it may be argued that participants' sportsmanship levels were above the moderate level.

Table 2. Mann Whitney-U Test Results concerning Sportsmanship Scale Scores in terms of Sex Variable

\begin{tabular}{llcccccc}
\hline Sportsmanship & Sex & $\mathbf{n}$ & $\overline{\mathbf{x}}_{\text {sorts }}$ & $\sum_{\text {sorts }}$ & $\mathbf{U}$ & $\mathbf{z}$ & $\mathbf{p}$ \\
\hline \multirow{2}{*}{ Rules } & Female & 25 & 75.42 & 1885.50 & & & \\
& Male & 123 & 74.31 & 9140.50 & 1514.50 & -0.12 & 0.91 \\
\hline \multirow{2}{*}{ Injurious Acts } & Female & 25 & 80.92 & 2023.00 & & & \\
& Male & 123 & 73.20 & 9003.00 & 1377.00 & -0.83 & 0.41 \\
\hline \multirow{2}{*}{ Opponent } & Female & 25 & 70.48 & 1762.00 & & & \multirow{2}{*}{0.60} \\
\hline \multirow{2}{*}{ Game Perspective } & Male & 123 & 75.32 & 9264.00 & 1437.00 & -0.52 & 0.607 \\
\hline \multirow{2}{*}{ Sportive Behavior } & Female & 25 & 60.70 & 1517.50 & \multirow{2}{*}{0.07} \\
\hline \multirow{2}{*}{ General Total } & Male & 123 & 77.30 & 9508.50 & 1192.50 & -1.79 & 0.07 \\
& Female & 25 & 72.28 & 1807.00 & \multirow{2}{*}{0.782 .00} & -0.29 & 0.78 \\
\hline & Male & 123 & 74.95 & 9219.00 & & & \multirow{2}{*}{0.10} \\
\hline
\end{tabular}


Gençer Y. G., Eroğlu, O., Yıldırım, Y. (2019). Investigation of Sportsmanship Orientation of Athletes Attending to Intercollegiate Basketball Competitions. International Journal of Recreation and Sport Science, 3 (1); 39-45.

When Table 2 was examined, it was identified that Sportsmanship Scale scores did not change significantly in terms of sex variable.

Table 3. Kruskal Wallis-H Test Results concerning Sportsmanship Scale Scores in terms of Position Variable

\begin{tabular}{|c|c|c|c|c|c|c|}
\hline Sportsmanship & Position & $\mathbf{n}$ & $\overline{\mathbf{x}}_{\text {sorts }}$ & $\mathbf{X}^{2}$ & sd & $\mathbf{p}$ \\
\hline \multirow{3}{*}{ Rules } & Guard & 58 & 68.28 & \multirow{3}{*}{3.10} & \multirow{3}{*}{2} & \multirow{3}{*}{0.21} \\
\hline & Forward & 73 & 80.76 & & & \\
\hline & Pivot & 17 & 68.82 & & & \\
\hline \multirow{3}{*}{ Injurious Acts } & Guard & 58 & 67.41 & \multirow{3}{*}{4.26} & \multirow{3}{*}{2} & \multirow{3}{*}{0.12} \\
\hline & Forward & 73 & 81.84 & & & \\
\hline & Pivot & 17 & 67.18 & & & \\
\hline \multirow{3}{*}{ Opponent } & Guard & 58 & 69.97 & \multirow{3}{*}{2.91} & \multirow{3}{*}{2} & \multirow{3}{*}{0.23} \\
\hline & Forward & 73 & 80.31 & & & \\
\hline & Pivot & 17 & 65.03 & & & \\
\hline \multirow{3}{*}{ Game Perspective } & Guard & 58 & 67.59 & \multirow{3}{*}{2.93} & \multirow{3}{*}{2} & \multirow{3}{*}{0.23} \\
\hline & Forward & 73 & 77.60 & & & \\
\hline & Pivot & 17 & 84.79 & & & \\
\hline \multirow{3}{*}{ Sportive Behavior } & Guard & 58 & 68.89 & \multirow{3}{*}{2.15} & \multirow{3}{*}{2} & \multirow{3}{*}{0.34} \\
\hline & Forward & 73 & 79.67 & & & \\
\hline & Pivot & 17 & 71.44 & & & \\
\hline \multirow{4}{*}{ General Total } & Guard & 58 & 67.16 & \multirow{4}{*}{3.39} & \multirow{4}{*}{2} & \multirow{4}{*}{0.18} \\
\hline & Forward & 73 & 80.90 & & & \\
\hline & Pivot & 17 & 72.06 & & & \\
\hline & Total & 148 & & & & \\
\hline
\end{tabular}

When Table 3 was examined, it was seen that Sportsmanship Scale scores did not differ statistically in terms of position variable.

Table 4. Mann Whitney-U Test Results concerning Sportsmanship Scale Scores in terms of Department Variable

\begin{tabular}{|c|c|c|c|c|c|c|c|}
\hline Sportsmanship & Department & $\mathbf{n}$ & $\overline{\mathbf{x}}_{\text {sorts }}$ & $\sum$ sorts & $\mathbf{U}$ & $\mathbf{z}$ & $\mathbf{p}$ \\
\hline \multirow{2}{*}{ Rules } & SPES & 111 & 75.62 & 8394.00 & & & \\
\hline & Other Departments & 37 & 71.14 & 2632.00 & 1929.00 & -0.55 & 0.58 \\
\hline \multirow{2}{*}{ Injurious Acts } & SPES & 111 & 76.41 & 8481.00 & & & \\
\hline & Other Departments & 37 & 68.78 & 2545.00 & 1842.00 & -0.94 & 0.35 \\
\hline \multirow{2}{*}{ Opponent } & SPES & 111 & 74.78 & 8300.50 & & & \\
\hline & Other Departments & 37 & 73.66 & 2725.50 & 2022.50 & -0.14 & 0.89 \\
\hline \multirow{2}{*}{ Game Perspective } & SPES & 111 & 74.82 & 8305.00 & & & \\
\hline & Other Departments & 37 & 73.54 & 2721.00 & 2018.00 & -0.16 & 0.07 \\
\hline \multirow{2}{*}{ Sportive Behavior } & SPES & 111 & 75.78 & 8411.50 & & & \\
\hline & Other Departments & 37 & 70.66 & 2614.50 & 1911.50 & -0.63 & 0.53 \\
\hline \multirow{3}{*}{ General Total } & SPES & 111 & 75.86 & 8420.50 & & & \\
\hline & Other Departments & 37 & 70.42 & 2605.50 & 1902.50 & -0.67 & 0.50 \\
\hline & Total & 148 & & & & & \\
\hline
\end{tabular}

$\mathrm{p}>0.05$

When Table 4 was examined, it was noted that Sportsmanship Scale scores did not differ statistically in terms of department variable 


\section{DISCUSSION AND CONCLUSION}

In the study; it was found that Sportive Behavior subdimension of the Sportsmanship Scale showed the highest score $(\bar{x}=4.15)$ while the lowest score was found in Injurious Acts subdimension $(\overline{\mathrm{x}}=3.88)$. In addition, it may be argued that participants' sportsmanship levels were above the moderate level (Table 1). In a study done by Güllü and Şahin (2018) with national wrestlers and another study done by Sezen Balçıkanlı, Gülşen and Yildiran (2017) done with female footballers; participants' sportsmanship levels were found to be at a higher level. Considering the fact that a high emphasis has lately been put on sportsmanship term, it may be suggested that findings obtained were positive; which -for us- may be due to the fact that sportsmanship term has become popular and been widely acclaimed.

In the study; it was noted that Sportsmanship Scale scores did not change significantly in terms of sex variable (Table 2). In literature, this study concurred with the study of Gürpınar and Kurşun (2013) that was done with basketballers and footballers while it did not concur with the study of Güllü and Şahin (2018) that was done with national wrestlers. The study of Coulomb-Cabagno and Rascle (2006) on handballers and footballers reported that male athletes were more aggressive than female athletes. Tsai and Fung (2005) stated that females accepted sportsmanship more than males. However, the study of Güllü and Şahin (2018) that was done with national wrestlers pointed out that male athletes had higher sportsmanship scores as compared to female athletes. This may have resulted from the possibility that though success in sportive competitions matters, these athletes participated in a non-profit sportive activity like Intercollegiate Sportive Competitions and wanted to represent their universities in the best possible way and their sportive branches were different.

In the study; it was found that Sportsmanship Scale scores did not differ statistically in terms of position variable (Table 3); which may be suggested that a wrong action of a basketballer in the team may affect the whole team and therefore all members of the team acted together in line with the team objectives. Besides, that players who perform nonsportsmanship behaviors/fouls are disqualified in basketball may be another reason of this finding.

In the study; it was noted that Sportsmanship Scale scores did not differ statistically in terms of department variable but students who attended School of Physical Education and Sports had higher sportsmanship scores than students of other departments in general scale and all subdimensions (Table 4). This may be due to the fact that students of School of Physical Education and Sports join sportive activities and are aware of the values of sport more than other students.

As a result; athletes participating in Intercollegiate Basketball Competitions had sportsmanship above the moderate level and their scores did not differ statistically in terms of sex, position and department variables. Besides, it may be said that students who attend School of Physical Education and Sports had higher level of sportsmanship than the students of other departments. Today, when sport violence is at its peak; importance of friendship, fraternity, respect, tolerance, gentilmanship -in short sportsmanshiphas been increasing. In this respect; it is very crucial for everyone that a generation with ethics and discipline in sports be raised (Altın and Özsar1, 2017).

It is recommended to conduct studies that will investigate athletes of different 
branches and cultures and thus will make contributions to literature.

\section{REFERENCES}

Altın, M. ve Özsar1, A. (2017). Sporcu Eğitim Merkezlerinde Yat11 Olarak Eğitim Gören Sporcuların Ahlaki Karar Alma Tutumları. Uluslararası Kültürel ve Sosyal Araştırmalar Dergisi, 3(1),133145.

Coulomb- Cabagno, G. and Rascle, O. (2006). Team Sports Players' Observed Aggresion as a Function of Gender, Competitive Level and Sport Type. Journal of Applied Social Psychology,36(8), 19802000.

Çalayır, Ö., Yıldız, N., Yaldız, Ö. ve Çoknaz, H. (2017). Hokey Müsabakalarına Katılan Sporcuların Beden Eğitimi Dersi Sportmenlik Davranışlarının İncelenmesi. Istanbul Üniversitesi Spor Bilimleri Dergisi,7(2), 2737.

Güllü, S. ve Şahin, S. (2018). Milli Güreşçilerin Sportmenlik Yönelim Düzeyleri Üzerine Bir Araştırma. Electronic Turkish Studies, 13(18), 705-718.

Gümüş, H. (2019). X Kuşağında Sportmenlik Yönelimi. OPUS Uluslararast Toplum Araştırmalart Dergisi, 10(17), 739-755.

Gümüş, H., Saraçlı, S., Karakullukçu, Ö. F., Doğanay, G. ve Kurtipek, S. (2016).

Ortaöğretim Öğrencilerinde Fair Play Kavram1. International Journal of Science Culture and Sport, 4(2), 430-438.

Gümüş, H., Saraçlı, S., Yağmur, R., Işık, Ö. ve Ersöz, Y. (2017). The
Investigation of Sportsmanship Behavior of University Students, Malaga/Spain, 18-24 September 2017.

Gürpınar, B. ve Güven Ö. (2011). Futbol Hakemlerinin Karşılaştıkları Sportmenlik Dişı Davranışların Incelenmesi. Spormetre Beden Eğitimi ve Spor Bilimleri Dergisi, 9(1), 7-14.

Özsarı, A., Demirel, H., Altın, M., Yalçın, Y. G. ve Demir, H. (2018.) Kadın Basketbolcuların Sportmenlik Yönelimleri. Türk Spor Bilimleri Dergisi, 1(2), 66-71.

Gürpınar, B. ve Kurşun, S. (2013). Basketbolcuların ve Futbolcuların Sportmenlik Yönelimleri. Mediterranean Journal of Humanities, 3(1), 171-176.

Özsarı, A. (2018). İşitme Engelli Voleybolcuların Sportmenlik Yönelimleri. Beden Eğitimi ve Spor Bilimleri Dergisi, 20(3), 112121.

Pehlivan, Z. (2004). Fair-Play Kavramının Geliştirilmesinde Okul Sporunun Yeri ve Önemi. Spormetre Beden Eğitimi ve Spor Bilimleri Dergisi, 2(2) 49-53.

Sezen-Balçıkanlı, G. ve Yıldıran, I. (2011). Profesyonel Futbolcularin Sportmenlik Yönelimleri ve Empatik Eğilim Düzeyleri. SPORMETRE Beden Ĕgitimi ve Spor Bilimleri Dergisi, 9(2), 49-56.

Sezen-Balçıkanlı, G., Gülşen, K. ve Yildıran, İ. (2017). Kadın Futbolcularda Sportmenlik Yönelimi. Gazi Beden Eğitimi ve Spor Bilimleri Dergisi, 22(1-4), 19.

Stornes, T. and Bru, E. (2002). Sportspersonship and Perceptions of Leadership: An Investigation of 
Adolescent Handball Players' Perception of Sportspersonship and Associations with Perceived Leadership. European Journal of Sport Science, 2(6), 1-15.

Tekeli, H. (2017). Ortaöğretim Öğrencilerinin Beden Eğitimi Dersinde Sportmenlik Davranışlar Sergileme Düzeylerinin Bazı Demografik Değişkenlere Göre Incelenmesi. (Yüksek Lisans Tezi). Mehmet Akif Ersoy Üniversitesi, Eğitim Bilimleri Enstitüsü, Burdur.
Tel, M., Yaman, Ç. ve Altun, M. (2017). Spor Bilimleri Fakültesi Öğrencilerinin Sportmenlik Davranışları Hakkındaki Görüşleri. International Journal of Cultural and Social Studies, 3, 1626.

Tsai, E. and Fung, L. (2005). Sportspersonship in Youth Basketball and Volleyball Players. AthleticInsight: The Online Journal of Sport Psychology, 7(2), 37-46. 